\title{
Preface and acknowledgements
}

This book is a film fan's labour of love, and a media scholar's consideration of what journalism - one of our key social and cultural institutions - is in our time, as refracted through the prism of one of our most important cultural forms. The films selected for discussion are those which I have found particularly useful in my academic work as a researcher and teacher of journalism, resonant in what they have to say about how journalism is perceived in liberal democratic societies, and engaging as a film lover. There are omissions, no doubt, and some readers may disagree with my choices and emphases. Suggestions on films which I have neglected to mention are welcome.

My thanks go to the University of Strathclyde for a semester of study leave in which to watch films and write about them, and to those journalists, academics and others who responded to my request for their views on their favourite films about journalism. Thanks to Katherine McNair for help in assembling film stills, tables and formatting of the final typescript, and to Tereza McLaughlinVanova for research and office support. Faye Hammill read and provided useful comments on 'Heroines'. 
